\begin{tabular}{|c|c|c|c|c|c|c|}
\hline \multirow{4}{*}{ Impact Factor: } & ISRA (India) & $=3.117$ & SIS (USA) & $=0.912$ & ICV (Poland) & $=6.630$ \\
\hline & ISI (Dubai, UAE & $=0.829$ & РИНЦ (Russia & $=\mathbf{0 . 1 5 6}$ & PIF (India) & $=1.940$ \\
\hline & GIF (Australia) & $=0.564$ & ESJI (KZ) & $=8.716$ & IBI (India) & $=4.260$ \\
\hline & JIF & $=1.500$ & SJIF (Morocco & $=\mathbf{5 . 6 6 7}$ & OAJI (USA) & $=0.350$ \\
\hline
\end{tabular}

\section{SOI: 1.1/TAS DOI: 10.15863/TAS International Scientific Journal Theoretical \& Applied Science}

p-ISSN: 2308-4944 (print) e-ISSN: 2409-0085 (online)

Year: $2019 \quad$ Issue: $04 \quad$ Volume: 72

Published: $30.04 .2019 \quad$ http://T-Science.org
QR - Issue

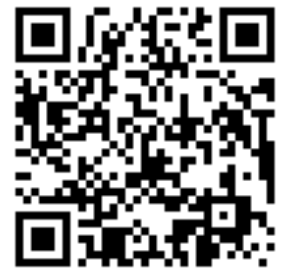

Zulfiya Nigmatullayevna Akmalova

teacher,

University of world economy and diplomacy

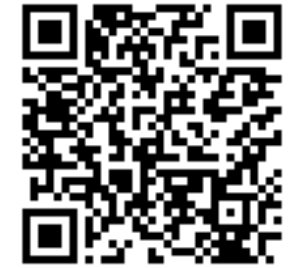

QR - Article

UDC 81-13

\title{
DIVERSITY OF MODERN METHODS IN THE TEACHING FOREIGN LANGUAGE
}

Abstract: This article purpose is highlights of modern methods in education, so diversity of modern methods in the teaching foreign language and importance of educational technologies in the effectiveness lesson, difficulties, problems and tasks.

Key words: foreign language, modern methods, teaching, learning, educational technologies, effectiveness, lesson.

Language: English

Citation: Akmalova, Z. N. (2019). Diversity of modern methods in the teaching foreign language. ISJ Theoretical \& Applied Science, 04 (72), 513-516.

Soi: http://s-o-i.org/1.1/TAS-04-72-66 Doi: crossef https://dx.doi.org/10.15863/TAS.2019.04.72.66

\section{Introduction}

In recent decades, great importance is given to the search for new or reconstruction of old, wellknown pedagogical science teaching methods that could ensure the relationship of educational, developmental and educational functions of education.

The new methods of teaching that are born often do not have a psychological and pedagogical justification, they are difficult to classify, but their use in the educational process brings students undoubted success. Let us give some of these methods as an example.

It is obvious that at the end of the XXI century in Uzbekistan there was a kind of revolution in the methods of teaching a foreign language. Previously, all priorities were given to grammar, almost mechanical mastery of vocabulary, reading and literary translation. Language acquisition was carried out through a long routine work.

\section{Materials and Methods}

Tasks were offered quite monotonous: reading the text, translation, memorizing new words, retelling, text exercises. When priorities were given to reading and working on conversational topics, only one function of the language was implemented informative. It is not surprising that only a few people knew the language well: only very purposeful and hardworking people could master it at a high level[1].
Today, language teaching has acquired an applied character, while previously it was relatively abstract and theoretical. Progress and fundamental changes in the methods of language learning, of course, associated with innovations in the field of psychology of personality and group. Now there are noticeable changes in people's minds and the development of new thinking: there is a proclaimed need for self-actualization and self-realization. The psychological factor of learning foreign languages is put forward in a leading position.

\section{The fundamental method}

Is the oldest and traditional method. That is how Lyceum students taught Latin and Greek, while French was absorbed naturally, along with the strict suggestions of governesses and communication with maman and papan. The fundamental technique relied seriously in language schools. The translator is never sure of his knowledge of a foreign language, he understands the unpredictability of speech situations. Being engaged in the classical method, students not only operate with a variety of lexical layers, but also learn to look at the world through the eyes of a native speaker. Perhaps the most famous representative of the classical methods of teaching a foreign language is N.Bonk. Her English textbooks have long become classics of the genre and have with stood the competition of recent years[2]. 


\begin{tabular}{|c|c|c|c|c|c|c|}
\hline \multirow{4}{*}{ Impact Factor: } & ISRA (India) & $=3.117$ & SIS (USA) & $=0.912$ & ICV (Poland) & $=6.630$ \\
\hline & ISI (Dubai, UAE & $=0.829$ & РИНЦ (Russia & $=0.156$ & PIF (India) & $=1.940$ \\
\hline & GIF (Australia) & $=0.564$ & ESJI (KZ) & $=8.716$ & IBI (India) & $=4.260$ \\
\hline & JIF & $=1.500$ & SJIF (Morocco & $=\mathbf{5 . 6 6 7}$ & OAJI (USA) & $=0.350$ \\
\hline
\end{tabular}

\section{Communicative method}

There are many different approaches to learning English and one of them is communicative approach or communicative approach. In the ranking of popularity among other methods of the English language, the first line is actively held by the method of teaching, which is based on a positively proven in the US and Europe communicative approach to teaching students. The main attention of this communicative method of teaching English pays the language learning process and aid in the avoidance of fear and the language barrier. The communicative approach was born in the 60-70 years in the UK. It was at that time that English began to become an international language. At that time, there were techniques such as grammatical translation technique, audio-lingual, etc. All of them had their disadvantages and people who studied English as a foreign language came to the conclusion that they did not meet their needs. The need of these people was to put into practice the knowledge gained, rather than systematic and in-depth language acquisition. People who learned English to communicate on it, did not know spoken language and knew nothing about verbal etiquette. That is, they felt disadvantaged during real communication. The purpose of this method was to teach people to communicate in real life. The method used many techniques that were used earlier in other techniques.

This method is different from others in that the educational fictional texts and far from real life texts that are studied by students in other methods are replaced by dialogues from everyday life. Students beat them in such a way as to cause each other to talk, that is, to motivate another person.

\section{Linguosociocultural method}

Linguosociocultural method involves contacting such a component as social and cultural environment. This method, which includes two aspects of communication - linguistic and intercultural, was born at the intersection of language and culture. Linguosociocultural method combines language structures (grammar, vocabulary, etc.).) with nonlinguistic factors. Then at the junction of the worldview on a national scale and language, that is, a kind of way of thinking is born the rich world of language, which wrote the linguist $\mathrm{V}$. von Humboldt: "through the diversity of language, we discover the richness of the world and the diversity of what we know in it..."Linguosociocultural method is based on the following axiom: "language is a social and cultural structures"[4]. We learn the world through thinking in a certain cultural area and use language to Express our impressions, opinions, emotions, perceptions. The purpose of language learning using this method is to facilitate the understanding of the interlocutor, the formation of perception on an intuitive level. Therefore, every student who has chosen such an organic and holistic approach should treat the language as a mirror reflecting the geography, climate, history of the people, the conditions of their life, traditions, everyday life, everyday behavior, creativity.

\section{Game education}

Game education - is to create a situation of choice and decision-making, which reproduced the conditions close to real. It assumes roles that enable participants to understand, experience and learn new functions. The game contains a specific event or phenomenon to be modeled, and it is allowed to refer the game time to any period (present, past, future). As a rule, a game education is a model of a segment of future professional activity of students. This is an imitation of the management, research, pedagogical real activity of the teacher, the head of the educational institution.

The distinctive features of the education game can be called: imitation of the real process in the game with the help of the model; the distribution of roles between the participants of the game, their interaction with each other; the difference in interests of the participants of the game and the emergence of conflict situations; the presence of a common game goal of the whole team, which is achieved in the process of interaction of players and unites all its participants; consideration of the results of activities; the implementation of a chain of decisions in the game, each of which depends on the previous, as well as on the decisions taken by other participants of the game. The undoubted advantage of education games is that they combine theory and practice, contributing to the formation of including professional knowledge and practical skills. Games increase interest in the subject, as they are accompanied by positive emotions.

\section{The intensive method}

An intensive procedure has been gaining Particular popularity of intensive methods of teaching English. The intensive method is aimed at the formation of "expressive speech behavior", and therefore often has a linguistic character. In good courses, you are likely to be provided with opportunities for unlimited communication and maximum realization of potential, and the "focus" of the course will get your needs. Each student will be able to feel like a person. And educational methods, most likely, will be dialogical communication and trainings[6].

In recent years, many of the ideas on which the theory of intensive education is based have become the property of the wider pedagogical community. Some of them are developed in scientific research, others are tested only in practice. Practice has shown that the use of even some provisions of intensive training gives positive results[7]. However, a fundamentally new quality in the educational process 


\begin{tabular}{|c|c|c|c|c|c|c|}
\hline \multirow{4}{*}{ Impact Factor: } & ISRA (India) & $=3.117$ & SIS (USA) & $=0.912$ & ICV (Poland) & $=6.630$ \\
\hline & ISI (Dubai, UAE & $=0.829$ & РИНЦ (Russia & $=0.156$ & PIF (India) & $=1.940$ \\
\hline & GIF (Australia) & $=0.564$ & ESJI (KZ) & $=8.716$ & IBI (India) & $=4.260$ \\
\hline & JIF & $=1.500$ & SJIF (Morocco & $=\mathbf{5 . 6 6 7}$ & OAJI (USA) & $=0.350$ \\
\hline
\end{tabular}

can be achieved only when all the provisions of intensive training, reflected in its principles, will be presented in an integrated system. The General scheme of the methodical system is presented as the relationship of the following main components: goals, content of the subject and the educational process, tools and methods.

\section{The emotional-semantic method}

The origins of the emotional-semantic method of learning foreign languages is the Bulgarian psychiatrist Lozanov, who worked with patients on his own method of psychocorrection. He created "interest groups" and learning a foreign language was a medical tool. In Moscow, the achievements of Lozanov used in 2 language schools: "System-3" and "School Kitaygorodskaya" of Course, the methods of Igor Shekhter and Galina Kitaygorodskaya as different from the system Lozanov as their students - from the patients of the Bulgarian doctor. School of the Kitaygorodskaya for 25 years working on the methodology based on the combination of lozanovski developments with the fundamental course, and takes both adults and children. Schechter's method involves the teacher's free language communication with students from the first lesson. Students choose a middle name, familiar to the native speaker of the studied language, and the corresponding "legend" architect from Glasgow, violinist from Palermo, etc[8].

The Essence of the method is that the phrases and constructions are remembered naturally. The school "System-3" refused to install the creator of the method, which claimed that the basic grammatical rules of the student must "reach" on their own. Grammar courses serve as bridges-links between the stages of learning (there are 3 ). It is assumed that after the first stage, the student will not be lost in the country of the studied language, after the second - he will not get lost in the grammar of his own monologue, and after the third he will be able to be a full participant in any discussion. As can be seen from the above analysis, today there is a huge variety of methods of teaching a foreign language. Schechter's method - emotional and semantic approach to teaching foreign languages - is a scientific direction in linguistics, which States that the development of a foreign language should be similar to the generation of speech in the native language [9]. The Schechter method refers to direct interactive game methods of active learning.

The method of immersion is based on the following main positions:

1. Students construct their own knowledge, so teachers must constantly open up to students the possibility of using the knowledge they already possess, and at the same time play an active role in their own learning.

2. Mastering literacy should be a natural consequence of the interest of the students themselves, so the students, as a great-two hundred forty-one, choose your own reading materials and write essays on topics that interest them.

3. Reading is understanding, i.e. revealing the meaning of the read text. It cannot be likened to a set of private skills located in a hierarchical sequence, which is enough to own to learn to read.

4. The main purpose of the ability to write - a message of information. Teachers allow students to choose their own topics for essays, have a positive attitude to their attempts at self-expression and organize an audience ready to listen to the student's work.

5. Mastering literacy is a natural process. Exchange of views and opinions is a significant contribution to the process of formation of students' knowledge. Teachers teach children to interact with each other in the process of reading and writing.

6. Willingness to take risks and make mistakes is a necessary condition for improvement in reading and writing. Through various levels of "fallacy", children form their own integral systems of written language, and teachers encourage students to be independent, self-organized and to treat their mistakes as a necessary part of learning.

\section{Conclusion}

Therefore, the main task of a modern foreign language teacher is to determine the goals, means, and most importantly methods. Then the choice of courses and curriculum will not be so difficult. The method of intensification of psycho-intellectual activity is intended for emotional impact on the group with the help of certain techniques of the leader: his charm, artistry and "sports" form of his logic. The teacher, who uses the oral technology of micro-discovery method in his activity, expresses two functions. On the one hand, he acts as a brainstorming conductor, on the other - as an improviser.

\section{References:}

1. Halskov, N. D. (2000). Modern methods of teaching foreign languages. Manual for teachers. (p.165). Moscow: ARCTI.
2. Dzhurinsky, A. N. (1999). History of pedagogy: textbook for students of pedagogical universities. (p.432). Moscow: VLADOS. 


\begin{tabular}{|c|c|c|c|c|c|c|}
\hline \multirow{4}{*}{ Impact Factor: } & ISRA (India) & $=3.117$ & SIS (USA) & $=0.912$ & ICV (Poland) & $=6.630$ \\
\hline & ISI (Dubai, UAE & $=0.829$ & РИНЦ (Russia & $=\mathbf{0 . 1 5 6}$ & PIF (India) & $=1.940$ \\
\hline & GIF (Australia) & $=0.564$ & ESJI (KZ) & $=8.716$ & IBI (India) & $=4.260$ \\
\hline & JIF & $=1.500$ & SJIF (Morocco & $=5.667$ & OAJI (USA) & $=0.350$ \\
\hline
\end{tabular}

3. Dzhurinsky, A. V. (2000). Pedagogy: history of pedagogical ideas: a Training manual. (p.352). Moscow: Pedagogical society of Russia.

4. Kodzhaspirov, G. M. (2005). Pedagogical dictionary: For students. higher. and average. PED. studies'. institutions. (p.176). Moscow: Publishing center "Academy".

5. Passov, E. I. (1985). Communicative method of teaching foreign language speaking: a Guide for foreign teachers. (p.208). Moscow: Education.

6. Ter-Minasova, S. G. (2000). Language and intercultural communication. (p.261). Moscow: Word.
7. Petrusinsshy, V. V. (1991). Intensivnye metody avtomatizirovannogo obucheniya. Moscow.

8. Sinitsyn, E. S. (2001). Teoriya tvorchestva, strukturnyy analiz myshleniya, metod mikrootkr'piy. Novosibirsk.

9. Slastenin, V. A., Isaev, I. F., Mishchenko, A. I., \& Shiyanov, E. N. (1998). Pedagogika. Moscow.

10. Khutorskoy, A. V. (1998). Evristicheskoe obuchenie: Teoriya, metodologiya, praktika. Moscow.

11. Ellis, A., \& Fouts, D. (1993). Pedagogicheskie innovatsii. Moscow. 